\title{
Motile cryptofauna of a coral reef: abundance, distribution and trophic potential
}

\author{
D. W. Klumpp, A. D. McKinnon, C. N. Mundy \\ Australian Institute of Marine Science, PMB 3, Townsville MSO, Queensland 4810, Australia
}

\begin{abstract}
The major groups of motile cryptofauna inhabiting dead coral substrata across several environmental zones of Davies Reef in the central Great Barrier Reef, Australia, have been quantified. In general terms of both numbers and biomass the main groups of epibenthic cryptofauna were harpacticoid copepods, gammarid amphipods, syllid polychaetes and gastropod molluscs. Other crustaceans abundant in some locations were isopods, tanaids and ostracods. Copepods comprised 55 to $60 \%$ of total number of cryptofauna over all reef locations and up to $28 \%$ of biomass. Polychaetes were usually the dominant biomass component of the fauna. Abundance of total cryptofauna varied with reef location, being highest on the fore-reef region in terms of both density and biomass. Damselfish territories were shown to be a refuge for cryptofauna in all locations of the reef. Mean density of animals inside territories was $58300 \mathrm{~m}^{-2}$, an average of 3.6 times higher than on adjacent, well-grazed surfaces. Cryptofaunal abundance was closely related to algal abundance and not complexity of the coral rock substratum. It is predicted that cryptofauna are significant consumers of epilithic algae and associated material in locations such as damselfish territories, on coral reefs.
\end{abstract}

\section{INTRODUCTION}

A recent review of the biology of cryptofaunal communities of hard substrata on coral reefs by Hutchings (1983) emphasized the inadequacies in our knowledge of these animals. Least studied are the motile cryptofauna which inhabit the surface of the substratum. These are referred to as 'opportunistic species' by Hutchings, as opposed to the endolithic forms, which bore into the coral rock. Motile forms utilize the spaces available among the extremely heterogeneous relief of dead coral rock and the epilithic algal community. This faunal community is a complex assemblage of mainly gastropod molluscs, polychaetes and microcrustaceans such as amphipods, copepods, tanaids, and isopods.

This fauna is thought to be important as prey for fish and macroinvertebrates on coral reefs (Vivien \& Peyrot-Clausade 1974, Leviten 1978). However, despite the known significance of small invertebrates as grazers in some other marine systems (Howard 1982, van Montfrans et al. 1982), few researchers have attempted to quantify the significance of these fauna in utilizing food resources on coral reefs. A number of studies on the manipulation of grazer access to substrata on reefs (e.g. Russ 1987) have indicated that the larger grazers, such as fish, are the major consumers of epilithic algae.
Carpenter (1986) judged the motile cryptofauna to be relatively insignificant as grazers on one Caribbean reef, but Brawley \& Adey (1981) demonstrated that they can have a substantial impact on algal biomass in areas protected from large-grazer disturbance and predation. Such areas may be found in wave-swept reef crests and algal ridges (Brawley \& Adey 1981, Carpenter 1986) and inside of damselfish territories (Lobel 1980). Despite these investigations, defining the proportional consumption attributable to specific grazer groups remains an underexplored area for research.

Here we seek to assess the trophic importance of motile cryptofauna on coral reefs. We report the variation in abundance of the major groups of motile cryptofauna, in terms of density and biomass, across major environmental (see Done 1983) and biotic zones on a reef in the central Great Barrier Reef. Damselfish territoriality is considered because of its established influence on the biotic and physical characteristics of coral reef substrate, both locally (see Klumpp et al. 1987) and generally (see Hinds \& Ballantine 1987). Substratum characteristics (algal biomass and complexity) are examined as predictors of faunal abundance. We then calculate a food consumption rate for the cryptofaunal community on Davies Reef using our data on faunal abundance and published allometric 
relationships between body mass and ingestion rate for small macroinvertebrates.

\section{MATERIALS AND METHODS}

Sample collection. A total of 175 samples of similarsized dead coral substrata were collected by SCUBA, during daylight, on 15 November 1985 from 7 locations on a transect across Davies Reef on the Great Barrier Reef (Fig. 1). The transect traversed the reef from front
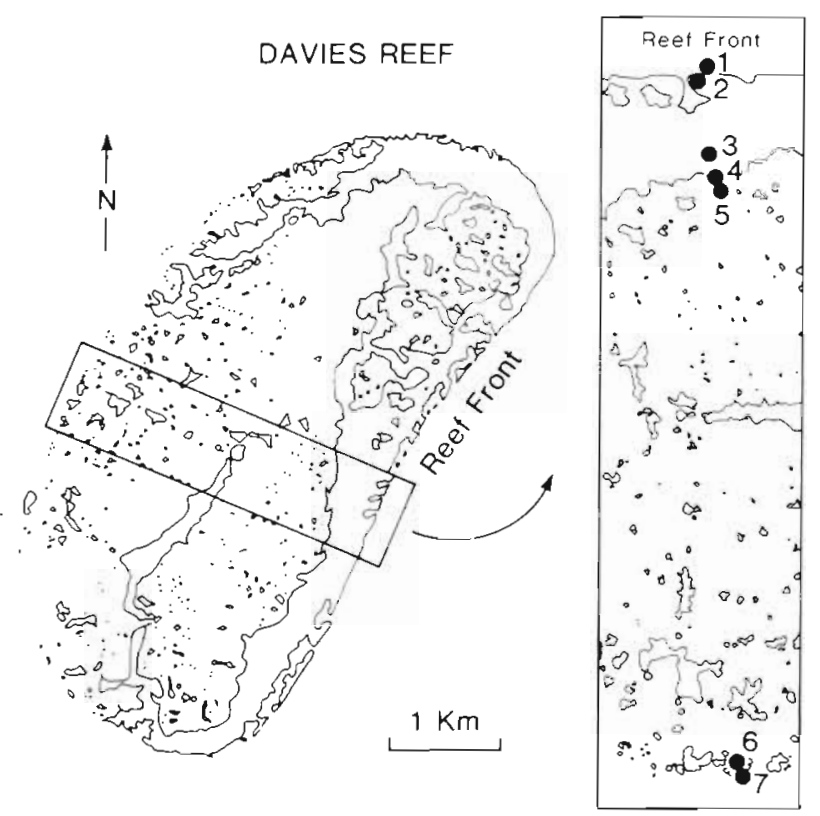

Fig. 1. Locations on Davies Reef where cryptofauna were collected

to back: Location 1 at $10 \mathrm{~m}$ depth on the front slope, Location 2 on the front crest, Locations 3 and 4 on the main flat, Location 5 at $10 \mathrm{~m}$ depth, where the main flat borders the lagoon, and Locations 6 and 7 on the outer back reef, on the flat and at $10 \mathrm{~m}$ depth, respectively. At each location, 5 replicate samples were taken at each of 6 sites, 3 of which were within fish territories and 3 from adjacent non-territory areas. Territories on reef flats and crests were those of the damselfish Stegastes apicalis and were easily identified by the presence of relatively luxuriant patches of filamentous algae. Only 2 fish-territory sites (of Plectroglyphidodon lacrymatus) were found at Location 1, and none at Locations 5 and 7 . Sampling was repeated in August 1986 at Locations 2 and 4, to provide an estimate of seasonal variation in abundance of cryptofauna. For these collections, 10 replicate samples were taken from both within and outside of fish territories, making a total of 40 samples.
Samples were taken by enclosing a piece of protruding dead coral substrate with a plastic bag and gently tapping with a masonry hammer to detach a coral block. Samples were immediately placed on ice for transport back to the laboratory.

Sample analysis. Small motile invertebrates inhabiting the epilithic algae and crevices on the surface of the coral rock (referred to hereafter as cryptofauna) were extracted in the laboratory in the following manner. Commencing $4 \mathrm{~h}$ after collection, the entire contents of a bag were poured into a $200 \mu \mathrm{m}$ sieve, which was then placed into a solution of $20 \%$ magnesium chloride in seawater for a period of ca $5 \mathrm{~min}$ to anaesthetize the fauna (Steedman 1976). Magnesium chloride was adopted as an extractant because it was expected to result in minimal effects on algal pigment composition, yet give an extraction efficiency as good as the more potent anaesthetics (e.g. MS 222). Test samples treated both prior to and in parallel to this sampling gave cryptofaunal extraction efficiencies of $90 \%$, relative to a total (formalin) extraction. Any animals too large to be washed through a sieve of $1 \mathrm{~cm}$ mesh were excluded from the analysis. The sieve was then removed from the anaesthetic solution and the coral block washed down into the sieve with a jet of filtered sea water. The block was then removed and frozen for subsequent pigment analysis, and the sieve residue, which comprised cryptofauna, algal fragments and detritus, was transferred to glutaraldehyde to preserve biomass (Kimmerer \& McKinnon 1986).

Cryptofauna were initially sorted from the sieve residue into 5 most common taxonomic groups: amphipods, copepods, other crustaceans, polychaetes and molluscs. Individuals within each of these groups were counted, and the group sample then placed on pre-combusted, tared aluminium pans for subsequent biomass measurement. For the crustacean component, separate counts of individuals were made to a finer taxonomic level (gammarideans, caprellids, isopods, cumaceans, tanaids, ostracods, decapods), although these were not discriminated in the biomass measurements. Samples for biomass (ash-free dry weight) were then dried for at least $48 \mathrm{~h}$ at $60^{\circ} \mathrm{C}$, weighed on a Mettler ME-22 microbalance, ashed at $500^{\circ} \mathrm{C}$ and reweighed. For comparative purposes, the proportions of organic matter to dry weight were: copepods $81 \%$, amphipods $72 \%$, other crustaceans $57 \%$, polychaetes $74 \%$, molluscs $21 \%$.

Chlorophyll a was used as an index of algal biomass present on the coral rock. Preliminary (and all subsequent) photosynthetic pigment analyses revealed that chlorophyll a was by far the predominant pigment present and that breakdown products (phaeopigments) averaged less than $5 \%$ of chlorophyll content. This method was thus judged to be the most appropriate for 
comparing algal biomass on the topographically complex coral substrata. Photosynthetic pigments of coral blocks were extracted in $90 \%$ acetone (with magnesium carbonate) for $24 \mathrm{~h}$. All extractions were carried out at $0^{\circ} \mathrm{C}$ and in the dark. Pigment optical density was read at $665 \mathrm{~nm}$ in a Varian Superscan 3 spectrophotometer before and after acidification ( $1 \mathrm{~N} \mathrm{HCl}$ ), to convert chlorophylls to phaeopigments. The amount of chlorophyll a present in each sample was calculated using the formula for periphyton as given in Vollenweider (1974). Serial extractions of the first 25 samples revealed an extraction efficiency of $70 \%$ in the first two 24-h extraction periods; subsequent samples were thus extracted for only 2 consecutive 24 -h periods and the data corrected for extraction efficiency.

Following pigment extraction the surface areas (SA) of the coral blocks were estimated using a latex-coating method. First the broken surface of each block, where it had been detached from the substrate, was coated with plaster of paris, thus leaving a smooth surface to facilitate the subsequent removal of latex from this part. The blocks were then dried in an oven at $60^{\circ} \mathrm{C}$ for $48 \mathrm{~h}$, and weighed. Then the blocks were immersed in a solution of rubber latex and re-dried. Prior to reweighing the blocks, the latex adhering to the plaster of paris surface was peeled off, leaving a coating of latex only on the originally exposed coral surface. Regression of weight increment against surface area for standards (a series of geometrically-regular coral blocks) of which the surface area had been calculated, gave a correlation coefficient value of 0.96 . The blocks were then photocopied, and their projected surface area (PSA) measured by digitising the photocopied images. The ratio of PSA to SA was taken as a measure of surface complexity.

Analysis of the August 1986 samples was as described above, except that biomass measurements were not made.

Data analysis. Data on biomass and density for total fauna and that of separate taxonomic categories (amphipods, copepods, other crustacea, polychaetes, molluscs) were examined in relation to location, territory status, algal biomass and surface complexity using 2-way nested analyses of variance (ANOVA). Preliminary analysis showed that variation in coral block size was not a factor influencing cryptofaunal abundance. Residual analysis of the raw data showed significantly heterogeneous variances, thus the data were transformed $(\log 10)$ to make the variances homogeneous Unavailable territory sites (Location 1 had only 2 territory sites, and Locations $5 \& 7$ were without territory sites) were treated as missing data. Where interactions were significant, F-values for the higher levels in the hierarchy were tested using the mean square for the significant interaction term as the denominator. Means for the ANOVAs were ranked using the Student-Newman-Keuls procedure. The interrelationship between cryptofaunal abundance and the variables algal biomass and substratum complexity was tested using multiple linear regression.

Calculation of ingestion rate. One of the major aims of this study was to provide preliminary estimates on the grazing rates of reef cryptofauna. Prior to attempting any detailed studies on feeding and direct measurement of ingestion rate in specific cryptofaunal groups, we have calculated the expected rate of food consumption by the reef cryptafaunal community based on our data for cryptofaunal abundance and the published allometric relation between measured ingestion rate and individual body mass (Cammen 1980, Peters 1983). The specific allometric relation used was that presented by Cammen (1980) for a wide range of benthic deposit feeders and detritivores representative of those of the present study $\left(r^{2}=0.98\right)$ : Ingestion rate $\left(\mathrm{mg}\right.$ dry $\left.w t \mathrm{~d}^{-1}\right)=0.435 \mathrm{~W}^{0.771} . \mathrm{OM}^{-0.920}$, where $\mathrm{W}=$ body mass (mg dry wt); OM = organic fraction of food. OM for epilithic algal communities on Davies Reef averages 0.75 (unpubl.). Consumption rate by a particular cryptofaunal group is then obtained by the product of either the inside or outside territory individual ingestion rate and the average density of that group for all locations. Total cryptofaunal community consumption is the sum of the group consumption rates. Feeding period was assumed to be 24 h (Robertson \& Mann 1980).

\section{RESULTS}

\section{Substratum characteristics}

Substratum complexity was significantly different across reef locations (Table $1 ; F$ test, $p<0.05$ ), with Location 5 being significantly more complex than all locations other than 7 , and Locations 1 and 3 being less complex than all other locations (SNK test). No difference in the complexity of substrata from inside and outside damselfish territories was detected, nor were there any significant interactions for substratum complexity.

The effect of territory on algal biomass was highly significant (Fig. 2; Table 1; F test, $p<0.001$ ), with algal biomass within damselfish territories being greater than outside damselfish territories (SNK test). The effect of location was highly significant (Fig. 2; Table 1; $F$ test, $p<0.001$ ) with greatest algal biomass on the reef flat and upper fore-reef slope (Locations 4, 3, and 2), and lowest biomass at the deeper back-reef Location 7 (SNK test). No significant interactions were found between the main effects of location and territory for algal biomass, however replicate sites within loca- 


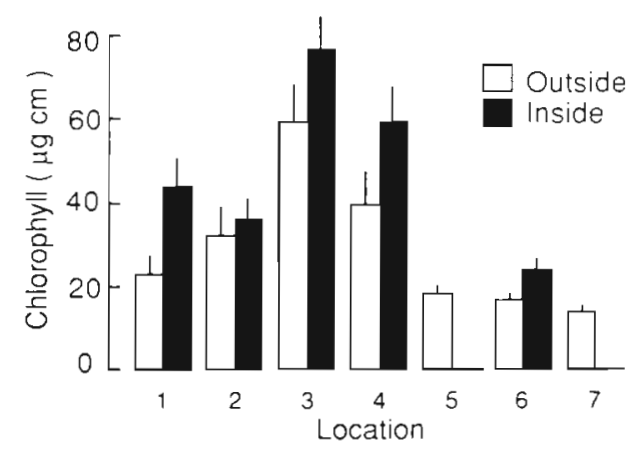

Fig. 2. Mean chlorophyll a values per unit area at different locations and sites across the Reef transect in summer

Table 1. Analysis of variance results for environmental data. Percentages of total sums of squares. Significance denoted by ' $p<0.05, \cdots p<0.01, \cdots p<0.001$

\begin{tabular}{|c|c|c|c|}
\hline Source & $\begin{array}{l}\text { Degrees of } \\
\text { freedom }\end{array}$ & $\begin{array}{c}\text { Algai } \\
\text { biomass }\end{array}$ & $\begin{array}{l}\text { Substratum } \\
\text { complexity }\end{array}$ \\
\hline & & $\cdots$ & $\cdots$ \\
\hline \multirow[t]{2}{*}{ Location } & 6 & 23.82 & 11.55 \\
\hline & & $\cdots$ & (ns) \\
\hline \multirow[t]{2}{*}{$\begin{array}{l}\text { Territory } \\
\text { status }\end{array}$} & 1 & 6.93 & 0.92 \\
\hline & & $\cdots$ & $\cdot$ \\
\hline $\begin{array}{l}\text { Site } \\
\text { (Location) }\end{array}$ & 14 & 13.48 & 5.89 \\
\hline $\begin{array}{l}\text { Location } \times \\
\text { Territory } \\
\text { status }\end{array}$ & 6 & $\begin{array}{l}\text { (ns) } \\
0.77\end{array}$ & $\begin{array}{l}\text { (ns) } \\
0.66\end{array}$ \\
\hline $\begin{array}{l}\text { Territory } \\
\text { status } \times \\
\text { Site } \\
\text { (Location) }\end{array}$ & 9 & $\begin{array}{l}\text { (ns) } \\
2.96\end{array}$ & $\begin{array}{l}\text { (ns) } \\
6.50\end{array}$ \\
\hline Residual & 137 & 44.81 & 73.29 \\
\hline
\end{tabular}

tion were found to be significantly different (Table $1 ; F$ test, $p<0.001$ ).

Exclusion of locations where no damselfish territories were found ( 5 \& 7) from the analyses resulted in replicate sites within locations becoming only marginally significant for algal biomass $(p<0.05)$, explaining $8.87 \%$ of the total variation, and non-significant for substratum complexity. Change in the significance of, and percentage of total variation explained by the main effects of location and territory status for both algal biomass and substratum complexity was negligible. This occurred similarly for the pooled density data, and therefore we regard this as an artifact of the missing territories rather than sites within location being significantly heterogeneous.

\section{Abundance and distribution of cryptofauna}

Density and biomass of cryptofauna were not significantly different (ANOVA; Tables $2 \& 3$ ) between replicate sites within each location, with the exception of the pooled faunal density data. Trends in the abundance of the cryptofaunal community along the reef transect, both inside and outside damselfish territories, are presented in Fig. 3. Most striking is the greater biomass and density of total cryptofauna occurring inside fish territories (on average $1.36 \mathrm{~g} \mathrm{AFDW} \mathrm{m}^{-2}$, 58300 animals $\mathrm{m}^{-2}$ ) compared with areas outside (on average $0.60 \mathrm{~g} \mathrm{AFDW} \mathrm{m}^{-2}, 16300$ animals $\mathrm{m}^{-2}$ ) at all locations on the reef.

Density. Density of total cryptofauna and each of the 5 taxa, except 'other crustaceans', did not vary significantly with location across the reef (ANOVA: $p<0.001$; Table 2). Densities of 'other crustaceans' were greater at Locations 1 and 6 than at other locations (SNK test; Fig. 4). All taxa occurred at significantly higher density inside damselfish territories than in adjacent non-territory areas (ANOVA: $p<0.05$; Table 2). The densities of copepods and polychaetes were significantly affected by the interactions of territory status and location on the reef (ANOVA: copepods $p<0.01$, polychaetes $p<0.05$; Table 2). At Locations 2 and 3 the differences in densities of both these taxa in adjacent territory and non-territory areas were more marked than at other locations (Fig. 4). In the case of polychaete density, there was a significant $(p<0.05)$ interaction of site within location with territory status.

Mean densities for the crustaceans, which were analysed in greater detail, are given in Table 4. Copepods, which were mainly harpacticoids of the families Peltidiidae and Thalestridae, occurred in densities up to 2870 ind. $100 \mathrm{~cm}^{-2}$ (a territory site at Location 4) and were always more abundant within territories. Similarly, ostracods were always more abundant within territories, but were more common at the reef flat and lagoon-edge locations. Gammarideans were the most common amphipods and were normally 3 to 4 times more abundant within territories, across the reef transect, and at Location 3 they were 25 times more abundant within territories, reaching a maximum abundance of 690 ind $100 \mathrm{~cm}^{-2}$. Common gammaridean families included the Gammaridae, Hyalidae and Lyssianidae. Caprellid amphipods were most abundant at the deeper sites on the reef front, and showed a slight preference for territories over non-territories, reaching a maximum abundance of 29 ind. $100 \mathrm{~cm}^{-2}$ at Location 1 The higher abundance of caprellids at deeper sites probably reflects their preference for lower energy environments. The opposite was true for the isopods, which were more common at exposed crest locations (2 and 6) where they occurred in greatest 
Table 2. Analysis of variance results for density data (numbers $\mathrm{cm}^{-2}$ ). Percentages of total sums of squares. Significance denoted by $p<0.05, \cdots p<0.01, \cdots p<0.001$. Degrees of freedom as in Table 1

\begin{tabular}{|c|c|c|c|c|c|c|}
\hline Source & Copepods & Amphipods & $\begin{array}{c}\text { Other } \\
\text { crustaceans }\end{array}$ & $\begin{array}{l}\text { Poly- } \\
\text { chaetes }\end{array}$ & Molluscs & Total \\
\hline & (ns) & (ns) & $\cdots$ & (ns) & (ns) & (ns) \\
\hline \multirow{2}{*}{ Location } & 2.67 & 14.75 & 12.64 & 13.61 & 4,48 & 2.71 \\
\hline & $\cdot$ & . & . & - & . & $\cdots$ \\
\hline \multirow{2}{*}{$\begin{array}{l}\text { Territory } \\
\text { status }\end{array}$} & 7.32 & 9.27 & 2.14 & 15.60 & 4.02 & 34.12 \\
\hline & (ns) & (ns) & (ns) & (ns) & (ns) & (ns) \\
\hline \multirow{2}{*}{$\begin{array}{l}\text { Site } \\
\text { (Location) }\end{array}$} & 4.82 & 3.87 & 7.12 & 5.75 & 9.70 & 8.20 \\
\hline & $\cdots$ & (ns) & (ns) & $\cdot$ & (ns) & (ns) \\
\hline \multirow{2}{*}{$\begin{array}{l}\text { Location } \times \\
\text { Territory } \\
\text { status }\end{array}$} & 5.78 & 6.01 & 2.42 & 6.74 & 1.84 & 5.31 \\
\hline & (ns) & (ns) & (ns) & $\cdot$ & (ns) & (ns) \\
\hline $\begin{array}{l}\text { Territory } \\
\text { status } \times \\
\text { Site } \\
\text { (Location) }\end{array}$ & 8.92 & 1.86 & 3.36 & 6.69 & 3.03 & 8.35 \\
\hline Residual & 71.75 & 53.39 & 70.38 & 46.40 & 72.32 & 34.68 \\
\hline
\end{tabular}

Table 3. Analysis of variance results for biomass data $\left(\mu \mathrm{g} \mathrm{cm}^{-2}\right)$. Percentages of total sums of squares. Significance denoted by $\cdot p<0.05, \cdots p<0.01, \cdots p<0.001$. Degrees of freedom as in Table 1

\begin{tabular}{|c|c|c|c|c|c|c|}
\hline Source & Copepods & Amphipods & $\begin{array}{c}\text { Other } \\
\text { crustaceans }\end{array}$ & $\begin{array}{c}\text { Poly- } \\
\text { chaetes }\end{array}$ & Molluscs & Total \\
\hline & (ns) & (ns) & $\cdots$ & $\cdots$ & (ns) & $\cdots$ \\
\hline \multirow[t]{2}{*}{ Location } & 8.61 & 11.37 & 28.45 & 19.59 & 3.11 & 14.42 \\
\hline & $\cdot$ & (ns) & (ns) & $\cdots$ & (ns) & $\cdots$ \\
\hline \multirow{2}{*}{$\begin{array}{l}\text { Territory } \\
\text { status }\end{array}$} & 34.93 & 10.22 & 0.81 & 6.87 & 0.01 & 1.47 \\
\hline & (ns) & (ns) & (ns) & (ns) & (ns) & (ns) \\
\hline \multirow{2}{*}{$\begin{array}{l}\text { Site } \\
\text { (Location) }\end{array}$} & 13.04 & 5.67 & 9.77 & 6.18 & 8.24 & 5.24 \\
\hline & $\cdots$ & $\cdots$ & (ns) & (ns) & . & (ns) \\
\hline \multirow{2}{*}{$\begin{array}{l}\text { Location } \times \\
\text { Territory } \\
\text { status }\end{array}$} & 2.44 & 6.70 & 5.10 & 2.25 & 9.67 & 4.52 \\
\hline & $\cdots$ & (ns) & $\cdot$ & (ns) & (ns) & (ns) \\
\hline $\begin{array}{l}\text { Territory } \\
\text { status } x \\
\text { Site } \\
\text { (Location) }\end{array}$ & 12.44 & 2.99 & 6.13 & 2.99 & 9.95 & 4.24 \\
\hline Residual & 26.49 & 53.36 & 47.96 & 58.06 & 68.82 & 70.11 \\
\hline
\end{tabular}

numbers within territories. The most common isopods were asellotes (Santia spp., Stenetrium sp./spp.) and the occasional anthuridean and sphaeromatid. Tanaids were most abundant within territories at Locations 1 and 6. Decapods (usually crabs or alpheid shrimps), due to their larger size, were usually excluded in the sieving process (200 to $1000 \mu \mathrm{m}$ ), and were not adequately sampled.

Biomass. Total biomass of cryptofauna (Fig. 3) differed significantly with both location on the reef and territory status (ANOVA: $p<0.001$; Table 3). Taken individually, only 2 taxonomic groups (other crusta- 

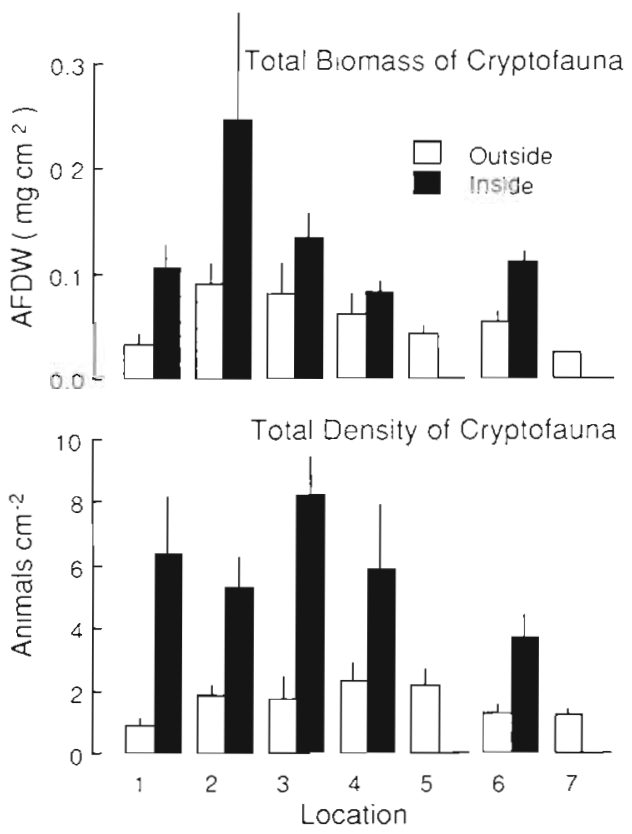

Fig. 3. Total abundance as biomass (upper) and density of cryptofauna (lower) at different locations and sites along the Reef transect in summer

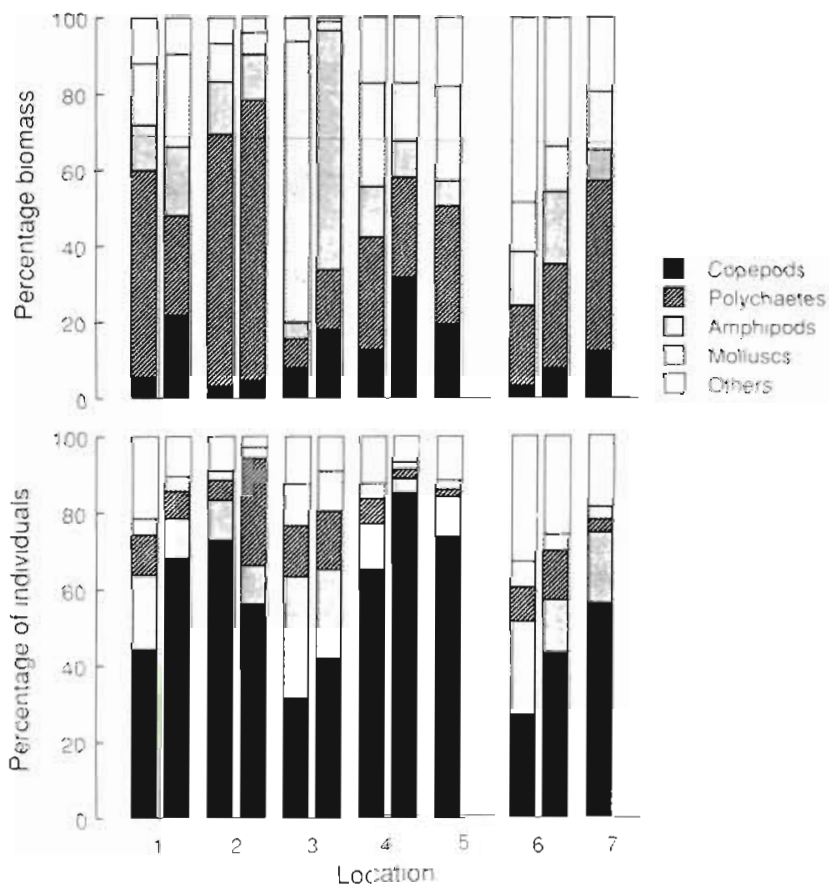

Fig. 4. Percentage contribution by major cryptofaunal groups to total biomass (upper) and total density (lower) at different locations and sites on Davies Reef. At each location, left column $=$ outside, right column $=$ inside territories

ceans and polychaetes) showed significant effects of location (ANOVA, $p<0.001$; Table 3 ). The back reefflat areas (Locations $4 \& 6$ ) had the highest biomass of other crustaceans, and polychaete biomass was signifi- cantly greater on the reef front at Locations 1 and 2 than at other locations (SNK test). Copepods and polychaetes were the only groups to show significant effects of territory status on their biomass (ANOVA: $p$ $<0.001$; Table 3); both showed greater biomass within territories than outside territories. Location and territory status had significant interactions for amphipod, copepod and mollusc biomass (ANOVA: copepods and amphipods $p<0.01$, molluscs $p<0.05$; Table 3 ) and for amphipods and molluscs, Location 3 was the source of this interaction (Fig. 4). Amphipod biomass was highest within territories of Location 3, whereas for molluscs the converse was true, their biomass outside territories at Location 3 being greatly increased. Biomass of copepods and of other crustacea had significant interactions of territory status and site within location (ANOVA: copepods $p<0.001$, other crustaceans $p<0.05$; Table 3).

Average body mass of animals, calculated from the density and biomass data presented above, was significantly lower for inhabitants of fish territories compared with animals living outside these territories in the case of amphipods ( $t$-test, $p<0.01$ ) and molluscs $(p<0.05)$. This observation explains why some faunal groups (amphipods, other crustaceans and molluscs) were more abundant inside territories in terms of numbers, but not of biomass.

Seasonal comparison. Algal biomass on the coral rock was significantly lower in August 1986 (winter) than in November (early summer) at territory sites in all locations sampled (2 \& 4), but not significantly different at sites outside fish territories (Table 5). Similarly the abundance of cryptofaunal groups was influenced more significantly by season within territory sites, than on the open grazed substrata. Numbers of amphipods and copepods were significantly lower ( $t$-test) in winter than in summer at most locations, with the exception of some non-territory sites. Abundance of molluscs was reduced in winter for all sites at Location 2 and polychaetes showed a reduction in abundance at the territory sites of this location. Density of other crustaceans was not affected by season.

\section{Factors affecting community composition}

Multiple regression analysis of cryptofaunal abundance on substratum complexity and algal biomass revealed that density of each taxonomic group was best predicted by algal biomass (chlorophyll a), both inside and outside fish territories (Table 6). In only one case (molluscs inside territories on the front slope), did complexity of substrata explain a significant proportion of the variance. Similarly, at Location 6 , territory sites, substrate complexity and algal biomass combined 
Table 4. Density of crustaceans for the Davies Reef transect. Mean numbers $100 \mathrm{~cm}^{-2}$; standard deviations in brackets. Locations are referred to by number and territory status $(\mathrm{O}$ : outside territories, or $\mathrm{T}$ : inside territories)

\begin{tabular}{|c|c|c|c|c|c|c|c|c|}
\hline Location & $N$ & Copepods & Ostracods & $\begin{array}{l}\text { Gamma- } \\
\text { rideans }\end{array}$ & Caprellids & Isopods & Tanaids & Decapods \\
\hline 10 & 15 & $\begin{array}{c}38.68 \\
(19.62)\end{array}$ & $\begin{array}{c}4.93 \\
(4.52)\end{array}$ & $\begin{array}{c}8.76 \\
(5.45)\end{array}$ & $\begin{array}{c}2.49 \\
(2.38)\end{array}$ & $\begin{array}{c}12.91 \\
(23.10)\end{array}$ & $\begin{array}{c}4.52 \\
(2.88)\end{array}$ & $\begin{array}{c}0.94 \\
(0.46)\end{array}$ \\
\hline $1 \mathrm{~T}$ & 10 & $\begin{array}{c}431.58 \\
(433.71)\end{array}$ & $\begin{array}{c}13.44 \\
(15.37)\end{array}$ & $\begin{array}{c}31.51 \\
(32.66)\end{array}$ & $\begin{array}{c}29.31 \\
(35.19)\end{array}$ & $\begin{array}{l}6.96 \\
(3.74)\end{array}$ & $\begin{array}{c}34.54 \\
(48.81)\end{array}$ & $\begin{array}{c}1.79 \\
(1.01)\end{array}$ \\
\hline 20 & 15 & $\begin{array}{c}58.92 \\
(46.64)\end{array}$ & $\begin{array}{c}5.18 \\
(3.97)\end{array}$ & $\begin{array}{c}24.51 \\
(16.27)\end{array}$ & $\begin{array}{c}2.31 \\
(3.29)\end{array}$ & $\begin{array}{c}13.98 \\
(10.77)\end{array}$ & $\begin{array}{c}5.47 \\
(5.75)\end{array}$ & \\
\hline $2 \Upsilon$ & 15 & $\begin{array}{c}222.72 \\
(154.36)\end{array}$ & $\begin{array}{l}13.39 \\
(7.03)\end{array}$ & $\begin{array}{c}77.18 \\
(71.01)\end{array}$ & $\begin{array}{l}3.03 \\
(2.46)\end{array}$ & $\begin{array}{c}28.48 \\
(11.89)\end{array}$ & $\begin{array}{c}8.75 \\
(5.64)\end{array}$ & $\begin{array}{c}0.51 \\
(0.21)\end{array}$ \\
\hline 30 & 15 & $\begin{array}{c}127.17 \\
(240.52)\end{array}$ & $\begin{array}{c}6.53 \\
(7.06)\end{array}$ & $\begin{array}{c}9.20 \\
(6.04)\end{array}$ & $\begin{array}{c}2.84 \\
(1.48)\end{array}$ & $\begin{array}{l}7.21 \\
(6.61)\end{array}$ & $\begin{array}{c}7.97 \\
(5.72)\end{array}$ & $\begin{array}{c}1.79 \\
(0.67)\end{array}$ \\
\hline $3 T$ & 14 & $\begin{array}{c}454.10 \\
(330.39)\end{array}$ & $\begin{array}{c}18.61 \\
(12.60)\end{array}$ & $\begin{array}{c}226.03 \\
(194.12)\end{array}$ & $\begin{array}{c}3.65 \\
(3.72)\end{array}$ & $\begin{array}{c}7.11 \\
(4.97)\end{array}$ & $\begin{array}{l}3.66 \\
(2.50)\end{array}$ & $\begin{array}{l}0.91 \\
(-)\end{array}$ \\
\hline 40 & 15 & $\begin{array}{c}149.25 \\
(163.62)\end{array}$ & $\begin{array}{c}12.19 \\
(15.73)\end{array}$ & $\begin{array}{c}14.9 \\
(22.61)\end{array}$ & $\begin{array}{c}2.45 \\
(2.32)\end{array}$ & $\begin{array}{c}9.61 \\
(8.14)\end{array}$ & $\begin{array}{c}9.06 \\
(7.72)\end{array}$ & $\begin{array}{c}1.91 \\
(1.60)\end{array}$ \\
\hline $4 \mathrm{~T}$ & 15 & $\begin{array}{c}479.06 \\
(676.76)\end{array}$ & $\begin{array}{c}25.63 \\
(46.81)\end{array}$ & $\begin{array}{l}12.39 \\
(8.35)\end{array}$ & $\begin{array}{l}3.19 \\
(2.47)\end{array}$ & $\begin{array}{l}10.00 \\
(9.55)\end{array}$ & $\begin{array}{l}3.50 \\
(2.45)\end{array}$ & $\begin{array}{c}1.63 \\
(0.85)\end{array}$ \\
\hline 50 & 15 & $\begin{array}{c}154.23 \\
(168.21)\end{array}$ & $\begin{array}{c}15.83 \\
(12.69)\end{array}$ & $\begin{array}{c}4.73 \\
(5.61)\end{array}$ & $\begin{array}{c}0.89 \\
(0.15)\end{array}$ & $\begin{array}{c}3.86 \\
(4.52)\end{array}$ & $\begin{array}{c}4.22 \\
(2.65)\end{array}$ & $\begin{array}{c}0.92 \\
(0.58)\end{array}$ \\
\hline 60 & 15 & $\begin{array}{c}34.44 \\
(23.79)\end{array}$ & $\begin{array}{c}4.47 \\
(4.53)\end{array}$ & $\begin{array}{l}10.39 \\
(8.65)\end{array}$ & $\begin{array}{l}6.25 \\
(-)\end{array}$ & $\begin{array}{c}24.78 \\
(26.55)\end{array}$ & $\begin{array}{c}13.28 \\
(11.20)\end{array}$ & $\begin{array}{c}0.89 \\
(0.25)\end{array}$ \\
\hline $6 \mathrm{~T}$ & 15 & $\begin{array}{l}165.46 \\
(84.30)\end{array}$ & $\begin{array}{c}12.67 \\
(12.41)\end{array}$ & $\begin{array}{c}43.56 \\
(48.15)\end{array}$ & $\begin{array}{c}7.18 \\
(10.60)\end{array}$ & $\begin{array}{c}38.40 \\
(30.57)\end{array}$ & $\begin{array}{c}45.46 \\
(46.43)\end{array}$ & $\begin{array}{c}1.35 \\
(0.83)\end{array}$ \\
\hline 70 & 15 & $\begin{array}{c}64.44 \\
(79.89)\end{array}$ & $\begin{array}{c}5.88 \\
(5.45)\end{array}$ & $\begin{array}{c}3.36 \\
(1.90)\end{array}$ & $\begin{array}{c}1.55 \\
(0.83)\end{array}$ & $\begin{array}{c}4.34 \\
(4.28)\end{array}$ & $\begin{array}{c}13.77 \\
(29.57)\end{array}$ & $\begin{array}{c}1.03 \\
(0.39)\end{array}$ \\
\hline
\end{tabular}

equally to give a significant correlation with molluscan density $(R=0.66, p=0.03)$. The relationship between cryptofaunal density and algal biomass was strongest for most faunal groups at the central reef region (Locations 2 to 4), especially where the fore-reef flat adjoins the lagoon. The weakest relationships between faunal density and either variable were found at the front and back reef margins. The pattern of relationshp between faunal density and algal biomass was identical for amphipods and copepods. Density values for other crustacea were less correlated with either substrate complexity or algal biomass.

\section{Food consumption rate}

Summarized data on the mean individual body mass and density of cryptofauna at all sites and locations on Davies Reef and the calculated (see 'Methods') rate of food consumption by cryptofauna are presented in Table 7 The major consumers are predicted to be molluscs and polychaetes on open grazed substrata, and copepods, amphipods and polychaetes within damselfish territories. Consumption is predicted to be greater within damselfish territories than open grazed areas for all taxa except for molluscs which are predicted to consume similar amounts of food in both situations. The total consumption of food by reef cryptofauna in fish territories (1882 $\mathrm{mg}$ dry $\mathrm{wt} \mathrm{m}^{-2} \mathrm{~d}^{-1}$ ) is 2.3 times higher than that in open grazed areas.

\section{DISCUSSION}

\section{Coral reef cryptofaunal communities}

Most investigations of cryptofauna on reefs around the world have centred on particular taxa (Table 8), especially the endolithic polychaetes (for details see Hutchings 1983). Studies on Caribbean motile cryptofauna in a range of taxonomic groups by Lobel (1980) in Panama and by Carpenter (1986) in St Croix suggest that abundance of these is reduced on Caribbean reefs relative to the Great Barrier Reef. The density of 
Table 5. Cryptofaunal density and chlorophyll for 2 locations (2 \& 4) in November 1985 and August 1986. Means and standard deviations for each taxon $100 \mathrm{~cm}^{-2}$. Chlorophyll numbers are $\mu \mathrm{g} 100 \mathrm{~cm}^{-2}$. Significant differences ( $t$-test) indicated by asterisks in right column. $p<0.05, \cdots p<0.01$, $\cdots p<0.001$

\begin{tabular}{|c|c|c|c|}
\hline & November 1985 & August 1986 & \\
\hline & \multicolumn{3}{|c|}{ Outside territories } \\
\hline Location 2 & & & \\
\hline Amphipods & $25.67 \pm 16.20$ & $8.50 \pm 6.75$ & $\cdots$ \\
\hline Copepods & $58.92 \pm 46.64$ & $64.39 \pm 73.05$ & \\
\hline Other crustaceans & $25.08 \pm 16.68$ & $39.97 \pm 65.42$ & \\
\hline Molluscs & $20.17 \pm 16.38$ & $6.92 \pm 8.39$ & $\cdot$ \\
\hline Polychaetes & $60.41 \pm 47.29$ & $36.74 \pm 34.46$ & \\
\hline Chlorophyll & $3188 \pm 2668$ & $1674 \pm 908$ & \\
\hline \multicolumn{4}{|l|}{ Location 4} \\
\hline Amphipods & $14.89 \pm 22.88$ & $18.76 \pm 39.65$ & \\
\hline Copepods & $147.76 \pm 163.62$ & $18.99 \pm 9.84$ & $\cdots$ \\
\hline Other crustareans & $27.75 \pm 25.33$ & $12.82 \pm 14.18$ & \\
\hline Molluscs & $10.12 \pm 9.42$ & $1.08 \pm 1.33$ & \\
\hline Polychaetes & $27.06 \pm 20.24$ & $8.39 \pm 6.56$ & \\
\hline \multirow[t]{2}{*}{ Chlorophyll } & $3892 \pm 3115$ & $3065 \pm 2250$ & \\
\hline & \multicolumn{3}{|c|}{ Inside territories } \\
\hline \multicolumn{4}{|l|}{ Location 2} \\
\hline Amphipods & $79.51 \pm 70.07$ & $28.71 \pm 18.83$ & $\cdot$ \\
\hline Copepods & $222.72 \pm 154.36$ & $104.94 \pm 52.04$ & $\cdot$ \\
\hline Other crustaceans & $47.29 \pm 19.58$ & $59.86 \pm 24.57$ & \\
\hline Molluscs & $57.63 \pm 41.02$ & $15.43 \pm 9.04$ & $\cdots$ \\
\hline Polychaetes & $124.79 \pm 140.96$ & $22.27 \pm 4.44$ & $\cdot$ \\
\hline Chlorophyll & $3534 \pm 1803$ & $1744 \pm 857$ & $\cdots$ \\
\hline \multicolumn{4}{|l|}{ Location 4} \\
\hline Amphipods & $14.31 \pm 8.24$ & $40.40 \pm 16.79$ & $\cdots$ \\
\hline Copepods & $472.30 \pm 654.37$ & $87.43 \pm 46.00$ & - \\
\hline Other crustaceans & $38.02 \pm 47.66$ & $12.82 \pm 14.18$ & \\
\hline Molluscs & $13.39 \pm 14.33$ & $5.61 \pm 6.70$ & \\
\hline Polychaetes & $24.31 \pm 15.38$ & $13.58 \pm 11.36$ & \\
\hline Chlorophyll & $5868 \pm 3230$ & $1542 \pm 624$ & $\cdots$ \\
\hline
\end{tabular}

amphipods and polychaetes reported by Carpenter (1986) was an order of magnitude less than on comparable substrata (fine algal turf and encrusting corallines) from across Davies Reef during both seasons. Gastropods were an important component of the Davies Reef fauna, especially in biomass terms, but these were not present in detectable numbers on the St Croix reef. Lobel (1980) also noted that small gastropods were rare in the Panama reefs he studied.

Our fish territory sites can best be compared with the data on cryptofaunal density presented by Lobel (1980), since in both cases the habitats comprise thick (up to $2 \mathrm{~cm}$ ) algal mats on coral substrata defended by a damselfish of the genus Stegastes. Again it is clear that the Davies Reef location is richer in cryptofauna than the Caribbean location, by at least a factor of 2 , and up to an order of magnitude for some taxa, but we cannot at this stage explain these differences.

\section{Damselfish territories: a refuge for cryptofauna}

Damselfish territories are now known to influence several aspects of the structure and processes of coral reefs. These territories increase reef algal biomass (Brawley \& Adey 1977, Williams 1981), diversity (Hixon \& Brostoff 1981, Sammarco 1983, Hinds \& Ballantine 1987, Scott \& Russ 1987) and productivity (Klumpp et al. 1987), reef erosion (Risk \& Sammarco 1982, Sammarco et al. 1986), sessile community structure (Vine 1974, Kaufman 1977, Sammarco \& Williams 1982 ) and probably the turnover of nutrients (Wilkinson \& Sammarco 1983, Polunin \& Koike 1987) and food resources (Russ 1987, Klumpp \& Polunin unpubl.). The present study has also shown that territories influence the abundance of reef motile cryptofauna. The cryptofauna inhabiting algal mats inside territories of Stegastes planifrons were reported by Lobel (1980) to be more abundant than on other algal-substrata; in this case mats of macroalgae, outside fish territories. The predominant type of substratum available to cryptofauna outside of fish territories on Davies Reef was not macroalgal, but that of a well-grazed filamentous and encrusting epilithic algal community. Nevertheless, the same pattern of enhanced cryptofaunal abundance inside damselfish territories compared with adjacent areas was found on Davies Reef. These differences in cryptofaunal abundance were consistently obvious in terms of density of all groups, and were highly significant for biomass of combined fauna, copepods and polychaetes.

\section{Factors influencing cryptofaunal abundance}

Abundance of small macroinvertebrates associated with marine plant communities (Heck \& Wetstone 1977, McBane \& Croker 1983, Hicks 1986) has been shown to be a function of the complexity and density of the plant substratum, and there is some evidence that the same applies to coral reef cryptofaunal communities. For example, crustaceans were found at higher densities among the densely-packed filaments of a calcareous green macroalga on a Puerto Rican reef than on the sparse blades of a seagrass (Stoner 1985). Several studies have demonstrated that the abundance of some epifauna (isopods, amphipods, tanaids, gastropods, polychaetes) of coral-rock substrata is correlated closely with algal biomass (Kohn \& Leviten 1976. Bailey-Brock et al. 1980, Miller 1982, Kensley 1984). Caging of the bare, heavily-grazed reef substrata on Eniwetak resulted in total coverage of algae and an order of magnitude increase in motile epifauna (Miller 1982). We reasoned that potential living space would vary with the degree of complexity of the coral-rock 
Table 6. Multiple regression analysis: cryptofaunal density on substratum complexity (Com) and chlorophyll content (Chl). Results from an analysis of variance of the regression are expressed as $p:{ }^{*}<0.05, \cdots<0.01, \cdots<0.001$; multiple correlation coefficient $R$. Independent variable (chlorophyll and complexity) listed where it alone explains a significant proportion of the variance ( $t$-tests, $p<0.05)$

\begin{tabular}{|c|c|c|c|c|c|}
\hline \multirow[t]{2}{*}{ Taxon } & \multirow[t]{2}{*}{ Location } & \multirow[t]{2}{*}{ Territory status } & \multicolumn{3}{|c|}{ Regression analysis results } \\
\hline & & & $p$ & $R$ & Important variable \\
\hline \multirow[t]{12}{*}{ Amphipods } & 1 & 0 & & 0.41 & \\
\hline & & $\mathrm{T}$ & & 0.55 & \\
\hline & 2 & $\mathrm{O}$ & & 0.44 & \\
\hline & & $\mathrm{T}$ & $\cdots$ & 0.77 & $\mathrm{Chl}$ \\
\hline & 3 & 0 & & 0.62 & Chl \\
\hline & & $\mathrm{T}$ & . & 0.67 & $\mathrm{Chl}$ \\
\hline & 4 & 0 & $\cdots$ & 0.93 & Chl \\
\hline & & $\mathrm{T}$ & $\cdots$ & 0.86 & Chl \\
\hline & 5 & $\mathrm{O}$ & . & 0.81 & Chl \\
\hline & 6 & $\mathrm{O}$ & & 0.40 & \\
\hline & & $\mathrm{T}$ & & 0.55 & \\
\hline & 7 & $\mathrm{O}$ & & 0.18 & \\
\hline \multirow[t]{12}{*}{ Copepods } & 1 & 0 & & 0.64 & Chl \\
\hline & & $\mathrm{T}$ & & 0.63 & \\
\hline & 2 & 0 & & 0.57 & \\
\hline & & $\mathrm{T}$ & • & 0.73 & Chl \\
\hline & 3 & 0 & & 0.52 & \\
\hline & & $\mathrm{T}$ & $\cdot$ & 0.81 & $\mathrm{Chl}$ \\
\hline & 4 & 0 & $\cdots$ & 0.88 & Chl \\
\hline & & $\mathrm{T}$ & $\cdot$ & 0.70 & Chl \\
\hline & 5 & $\mathrm{O}$ & · & 0.65 & Chl \\
\hline & 6 & $\mathrm{O}$ & & 0.53 & $\mathrm{Chl}$ \\
\hline & & $\mathrm{T}$ & & 0.29 & \\
\hline & 7 & 0 & & 0.19 & \\
\hline \multirow{12}{*}{ Other crustaceans } & 1 & $\mathrm{O}$ & & 0.19 & \\
\hline & & $T$ & & 0.65 & \\
\hline & 2 & O & & 0.64 & \\
\hline & & $\mathrm{T}$ & & 0.41 & \\
\hline & 3 & $\mathrm{O}$ & & 0.31 & \\
\hline & & T & & 0.44 & \\
\hline & 4 & O & & 0.47 & \\
\hline & & T & - & 0.82 & $\mathrm{Chl}$ \\
\hline & 5 & O & & 0.59 & \\
\hline & 6 & O & & 0.28 & \\
\hline & & $T$ & & 0.34 & \\
\hline & 7 & O & & 0.21 & \\
\hline \multirow[t]{12}{*}{ Molluscs } & 1 & O & & 0.47 & \\
\hline & & $\mathrm{T}$ & $\cdot$ & 0.81 & Com \\
\hline & 2 & 0 & & 0.55 & \\
\hline & & T & $\cdot$ & 0.78 & Chl \\
\hline & 3 & 0 & & 0.26 & \\
\hline & & T & & 0.40 & \\
\hline & 4 & 0 & $\cdots$ & 0.84 & Chl \\
\hline & & T & $\cdots$ & 0.85 & $\mathrm{Chl}$ \\
\hline & 5 & $\mathrm{O}$ & & 0.56 & \\
\hline & 6 & O & & 0.25 & \\
\hline & & $\mathrm{T}$ & $\cdot$ & 0.66 & \\
\hline & 7 & O & & 0.32 & \\
\hline \multirow[t]{12}{*}{ Polychaetes } & 1 & O & & 0.28 & \\
\hline & & $\mathrm{T}$ & $\because$ & 0.95 & $\mathrm{Chl}$ \\
\hline & 2 & O & $\cdots$ & 0.75 & \\
\hline & & T & & 0.41 & \\
\hline & 3 & 0 & & 0.25 & \\
\hline & & $\mathrm{T}$ & $\cdot$ & 0.68 & Chl \\
\hline & 4 & O & & 0.49 & \\
\hline & & $\mathrm{T}$ & $\cdots$ & 0.76 & $\mathrm{Chl}$ \\
\hline & 5 & O & $\cdots$ & 0.74 & Chl \\
\hline & 6 & O & & 0.54 & $\mathrm{Chl}$ \\
\hline & & $\mathrm{T}$ & & 0.54 & \\
\hline & 7 & 0 & & 0.37 & \\
\hline
\end{tabular}


Table 7. Summarized density and body mass (dry weight) values and calculated ingestion rate per animal and community consumption rate (see 'Methods') for major taxa of cryptofauna on Davies Reef. $O$ : outside territories; $T$ : inside territories. Mass in dry weight

\begin{tabular}{|c|c|c|c|c|}
\hline Group & $\begin{array}{l}\text { Density } \\
\text { (ind. } \mathrm{m}^{-2} \text { ) }\end{array}$ & $\begin{array}{l}\text { Body mass } \\
\qquad(\mu g)\end{array}$ & $\begin{array}{l}\text { Ingestion } \\
\left(\mu \mathrm{g} \mathrm{d}^{-1}\right)\end{array}$ & $\begin{array}{l}\text { Community consumption } \\
\qquad\left(\mathrm{mg} \mathrm{m}^{-2} \mathrm{~d}^{-1}\right)\end{array}$ \\
\hline \multicolumn{5}{|c|}{ Copepods } \\
\hline 0 & 8936 & 6.5 & 11 & 104 \\
\hline $\mathrm{T}$ & 34716 & 6.5 & 11 & 405 \\
\hline \multicolumn{5}{|c|}{ Amphipods } \\
\hline 0 & 1137 & 68 & 71 & 81 \\
\hline $\mathrm{T}$ & 8390 & 44 & 51 & 428 \\
\hline \multicolumn{5}{|c|}{ Other crustaceans } \\
\hline $\mathrm{O}$ & 2506 & 62 & 66 & 166 \\
\hline $\mathrm{T}$ & 5459 & 31 & 39 & 212 \\
\hline \multicolumn{5}{|c|}{ Molluscs } \\
\hline $\mathrm{O}$ & 908 & 334 & 243 & 220 \\
\hline $\mathrm{T}$ & 2738 & 97 & 94 & 257 \\
\hline \multicolumn{5}{|c|}{ Polychaetes } \\
\hline 0 & 2809 & 85 & 85 & 238 \\
\hline $\mathrm{T}$ & 7041 & 82 & 82 & 580 \\
\hline \multicolumn{5}{|c|}{ Total ${ }^{*}$ community } \\
\hline $\mathrm{O}$ & 16297 & & & 809 \\
\hline $\mathrm{T}$ & 58344 & & & 1882 \\
\hline
\end{tabular}

Table 8. Density of mobile cryptofauna on coral reefs. Cop: copepods, Amp: amphipods, Iso: isopods, Tan: tanaids, Ocr: other crustaceans, Pol: polychaetes, Gas: gastropods

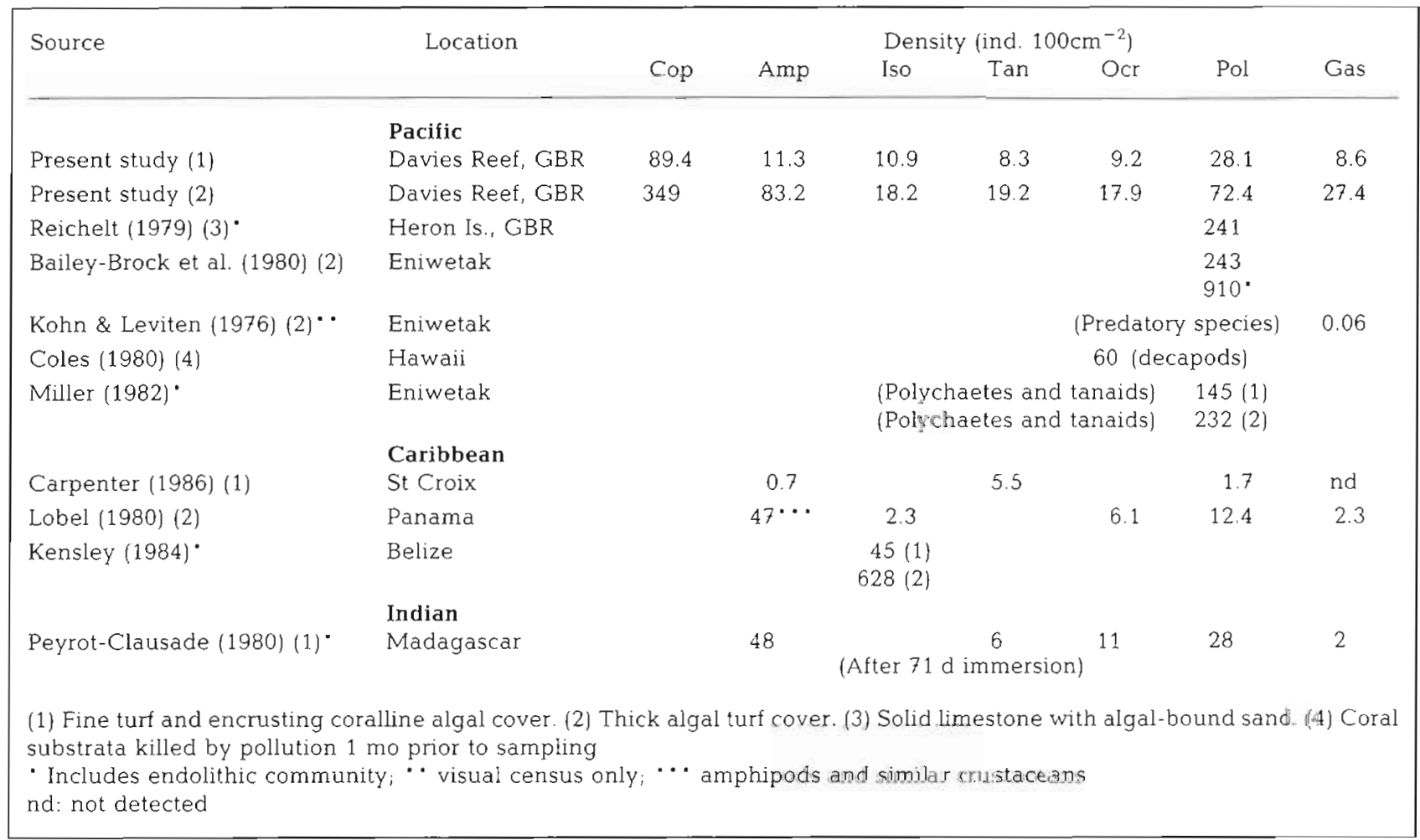


substratum, which would therefore influence cryptofaunal density. Analyses indicated that algal biomass, rather than complexity of the coral substratum, mainly determined cryptofaunal abundance both inside and outside damselfish territories. However, an increase in algal biomass itself represents an increase in substratum micro-heterogeneity, and therefore irrespective of the substratum complexity, an increase in cryptofaunal abundance would be expected. Other evidence for the interaction between algal density and cryptofaunal abundance comes from our studies on the seasonal response of the algae and fauna. Algal biomass per surface area on Davies Reef, in terms of organic carbon (Klumpp et al. 1987) and chlorophyll a (Table 5), decreases significantly from summer to winter within fish territories, but not on the open grazed surfaces. The abundance of most cryptofaunal groups appears to fluctuate in a similar manner.

The correlation between faunal abundance and algal density has been explained on the basis that dense algal filaments provide (a) protection from predation and environmental stress and (b) additional resources such as living space and food. The examination of these interactions on coral reefs is rare. Lobel (1980) postulated that the uneaten, underlying dense mat of red algae, that was defended by the territorial damselfish Stegastes planifrons, provided cryptofauna with a stable 'refuge' from heavy predation by reef fishes. Amphipods from Hawaiian coral reefs selected substrata irrespective of their complexity, as mimicked by bristle density of bottle brushes, but subsequent predation of amphipods by the damselfish Abudefduf sordidus was mediated by habitat complexity (Russo 1987). Similarly, Coles (1980) concluded that crustacean abundance on dead coral surfaces on Hawaiian reefs was determined initially by random colonization from the reef environment. Controlled experimentation in other ecosystems has shown that both the physical and biotic characteristics of natural substrata, such as relief and food content, influence choice of habitat, and therefore spatial patterns of abundance, for amphipods and other small invertebrates (see DeWitt 1987)

Environmental stresses, such as intense wave action and exposure to extremes of temperature, insolation and dessication, are likely to be ameliorated for fauna inhabiting dense algal mats. On coral reefs, these stresses are expected to be severest on the flat, especially at the exposed crest. On Davies Reef, the front reef crest (Location 2) is expected to be the most stressful location in that here one finds the greatest surge and wave force as well as exposure, albeit on the rare occasions of extreme low tides. However, there was no evidence to suggest that such stresses were acting to reduce the abundance of the more vulnerable crypto- faunal communities in sparse algal-covered and exposed areas of Davies Reef.

It is possible that the relative abundance of cryptofauna inhabiting dense mats of algal turfs is related to space and food resource availability (Stoner 1980, DeWitt 1987). Our results show that the availability of algal living space per unit area of coral substratum on reefs was an important variable controlling cryptofaunal density. Lobel (1980) reported that, as algal cover was grazed, cryptofauna redistributed themselves over the coral substratum in proportion to available algal surface. Similarly, crustaceans which colonized dying corals were found in numbers directly related to available space of the habitat (Coles 1980). Dense mats of algae, such as those found inside damselfish territories, will also provide a relatively rich and varied food resource of an algal, animal and detrital nature (Bailey-Brock et al. 1980, Lobel 1980, Hinds \& Ballantine 1987). There is only limited information on the food and feeding rates of reef cryptofauna, some of which are demersal plankton that also feed in the water column (Sale et al. 1976, Alldredge \& King 1977). Without this knowledge we cannot determine to what extent food resources provided within areas of sparse algal cover on reefs limit cryptofaunal abundance.

\section{Trophic potential}

Polychaetes, gastropod molluscs, copepods, amphipods and other small crustaceans (isopods, tanaids, ostracods) each made a substantial contribution to the biomass of the mobile cryptofaunal community on Davies Reef. On other reefs the same groups seem to dominate, although not necessarily in similar proportions (Lobel 1980, Peyrot-Clausade 1980, Miller 1982, Carpenter 1986). It has been proposed that cryptofauna are important consumers of coral mucus on reefs (Hutchings 1983). Although it has been noted that the information on feeding behavior for most of these groups is scarce, a substantial proportion of the community are likely to utilize the algal substratum as food, especially the micro-forms.

On Davies Reef, the most common polychaetes were the diminutive Syllidae, as is generally found on other coral reefs (Kohn \& Lloyd 1973, Alldredge \& King 1977. Reichelt 1979, Peyrot-Clausade 1980). Syllids have been classified as being both herbivorous and carnivorous (Fauchald \& Jumars 1979, Gaston 1987), and are characterized by piercing mouthparts with which they suck out the contents of algal and animal cells. Neumann et al. (1970), cited in Fauchald \& Jumars (1979), showed that some syllids are important grazers on coral reef algal mats. Most molluscs found on Davies Reef were small gastropods. There are no data on the 
diet of reef snails, but in other systems members of this group are general grazers, feeding on diatom crusts, blue-green algae and newly settled filamentous algae (Nicotri 1977, van Montfrans et al. 1982). Gammarid amphipods were one of the most important components of the crustacean fauna in biomass terms. Gammarids are recognized as one of the dominant grazers of microand macroalgae in temperate waters (Greze 1968, Brenner et al. 1976, McBane \& Croker 1983, Vadas 1985), but have been described often as both omnivorous (Macko et al. 1982, Wakabara et al. 1983) and detritivorous (Zimmerman et al. 1979). Gammarid amphipods in a coral reef microcosm were shown to graze the filamentous algal community (Brawley \& Adey 1981), many species of which were common to the Davies Reef damselfish territories (Klumpp \& Polunin unpubl.). Isopods of the Davies Reef cryptofauna were mainly asellotes which are described by Kensley (1984) to be numerous and widespread on coral reefs, where they appear to consume a mixture of detritus, diatoms, bacteria and protozoans. The copepods present in our samples were almost totally harpacticoids, whose primary food is microalgal (diatom) films in marine benthic systems (Sellner 1976, Hicks \& Coull 1983, Carmen \& Thistle 1985)

It seems that on open surfaces of coral reefs the density of micrograzers is kept low by intensive fish disturbance and predation (Vadas 1985, Carpenter 1986). In the absence of fish predation, grazing impact due to cryptofauna may become significant (Brawley \& Adey 1981). Carpenter (1986) concluded that cryptofauna were unlikely to be important grazers upon the fine epilithic algal community on the St Croix reef; however, the highest densities which he observed $(10$ ind. $100 \mathrm{~cm}^{-2}$ in summer) were only one sixth that of similar cryptofaunal groups on Davies Reef non-territory surfaces. Brawley and Adey (1981) noted that the disappearance of cultured filamentous algae in a reef microcosm corresponded with an amphipod density of greater than 1 ind. $\mathrm{cm}^{-2}$. In nature, these levels of amphipod abundance are found inside damselfish territories, as shown for the Caribbean (Lobel 1980) and for Davies Reef (overall mean of 84 ind. $100 \mathrm{~cm}^{-2}$, maximum 270 ind. $100 \mathrm{~cm}^{-2}$ at Location 4).

Although there are no empirical data on diets and ingestion rates for reef cryptofauna, our calculated rates of ingestion for these fauna appear reasonable as preliminary estimates. Recent measurements on feeding rates in harpacticoid copepods (Hicks \& Coull 1983) and gammarid amphipods (Zimmerman et al. 1979, Robertson \& Lucas 1983) agree well with our calculated rates. An extensive data base confirms that the slope of the relationship between ingestion and body size for poikilotherms approximates 0.80 (Peters 1983). However, there is less confidence in the intercept used in our calculation because this is most likely to be influenced by environmental factors such as temperature (Forbes \& Lopez 1987)

From the comparison of our preliminary ingestion rates for cryptofauna with known biomass and productivity of epilithic algal communities at the same sites and season (surnmer) on Davies Reef (Klumpp et al. 1987, Klumpp \& McKinnon unpubl.), it is predicted that motile cryptofauna are significant consumers in some locations, especially fish territories. It is interesting that the estimated total daily ingestion and net primary production rates were similarly elevated inside fish territories compared with open grazed zones (a factor of 2.3 and 3.4 respectively). Within damselfish territories, cryptofauna could consume daily only $1.0 \%$ of the biomass of epilithic algal material, but $31 \%$ of the net areal production in early summer $(2.145 \mathrm{gC}$ $\left.\mathrm{m}^{-2} \mathrm{~d}^{-1}\right)$. Outside of damselfish territories, where biomass and production of algae are less $(50 \%$ and $70 \%$ respectively, in early summer), cryptofauna appear to consume $1.0 \%$ of standing crop and $19 \%$ of the net areal production. These estimates for cryptofaunal ingestion rates complement the recent study by Russ (1987), which concluded that consumption by large grazers (mainly fish) in the central Great Barrier Reef accounted for $80 \%$ and $70 \%$ of net algal production inside and outside of damselfish (Stegastes fasciolatus) territories, respectively.

Acknowledgements. We thank Professor M. Pichon, Dr Russell Reichelt and 2 anonymous reviewers for helpful comments on the manuscript. Contribution No. 411 from the Australian Institute of Marine Science.

\section{LITERATURE CITED}

Alldredge, A. L., King, J. M. (1977). Distribution, abundance, and substrate preferences of demersal reef zooplankton at Lizard Island lagoon, Great Barrier Reef. Mar. Biol. 41: $317-333$

Bailey-Brock, J. H., White, J. K., Ward, L. A. (1980). Effects of algal turf and depressions as refuges on polychaete assemblages of a windward reef bench at Enewetak Atoll. Micronesica 16: 43-58

Brawley, S. H., Adey, W. H. (1977). Territorial behavior of threespot damselfish (Eupomacentrus planifrons) increases reef algal biomass and productivity. Environ. Biol. Fish. 2: 4.5-51

Brawley, S. H., Adey, W. H. (1981). The effect of micrograzers on algal community structure in a coral reef microcosm. Mar Biol. 61: 167-177

Brenner, D., Valiella, I., van Raalte, C. D. (1976). Grazing by Talorchestia longicornis on an algal mat in a New England salt marsh. J. exp. mar Biol. Ecol. 22: 161-169

Cammen, L. M. (1980). Ingestion rate: an empirical model for aquatic deposit feeders and detritivores. Oecologia (Berl.) 44: 303-310

Carmen, K. R., Thistle, D. (1985). Microbial food partitioning by three species of benthic copepods. Mar. Biol. 88: $143-148$ 
Carpenter, R. C. (1986). Partitioning herbivory and its effects on coral reef algal communities. Ecol. Monogr. 56: 345-363

Coles, S. L. (1980). Species diversity of decapods associated with living and dead reef coral Pocillopora meandrina. Mar Ecol. Prog. Ser. 2: 281-291

DeWitt, T H. (1987). Microhabitat selection and colonization rates of a benthic amphipod. Mar Ecol. Prog. Ser 36: $237-250$

Done, T. J. (1983). Coral zonation: its nature and significance In: Barnes, D. J. (ed.) Perspectives on coral reefs. Australian Institute of Marine Science. Townsville, p. 200-208

Fauchald, K., Jumars, P. A. (1979). The diet of worms: a study of polychaete feeding guilds. Oceanogr mar Biol. A. Rev. 17: $193-284$

Forbes, T L., Lopez, G. R. (1987). The allometry of deposit feeding in Capitella species I: the role of temperature and pellet weight in the control of egestion. Biol. Bull. mar biol. Lab., Woods Hole 172: 187-201

Gaston, G. R. (1987). Benthic Polychaeta of the middle Atlantic Bight: feeding and distribution. Mar. Ecol. Prog. Ser. 36: $251-262$

Greze, I. I. (1968). Feeding habits and food requirements of some amphipods in the Black Sea. Mar. Biol. 1: 316-321

Heck, K. L., Wetstone, G. S. (1977). Habitat complexity and invertebrate species richness and abundance in tropical seagrass meadows. J. Biogeography 4: 135-142

Hicks, G. R. (1986). Distribution and behavior of meiofaunal copepods inside and outside seagrass beds. Mar. Ecol Prog. Ser. 31: 159-170

Hicks, G. R., Coull, B. C. (1983). The ecology of marine meiobenthic harpacticoid copepods. Oceanogr. mar. Biol A. Rev. 21: $67-175$

Hinds, P. A., Ballantine, D. L. (1987). Effects of the Caribbean three-spot damselfish, Stegastes planifrons on algal lawn composition. Aquat. Bot. 27: 299-308

Hixon, M. A., Brostoff, W. N. (1981). Fish grazing and community structure of Hawaiian reef algae. In: Proc. 4th Int Coral Reef Symp. 2: 507-514

Howard, R. K. (1982). Impact of feeding activity of epibenthic amphipods on surface-fouling of eelgrass leaves. Aquat Bot. 14: 91-97

Hutchings, P. (1983). Cryptofaunal communities of coral reefs. In: Barnes, J. D. (ed.) Perspectives on coral reefs. Australian Institute of Marine Science, Townsville, p. 200-208

Kaufman, L. (1977). The three-spot damselfish: effects on benthic biota of Caribbean coral reefs. In: Proc. 3rd Int Coral Reef Symp., Miami, Florida, p. 559-564

Kensley, B. (1984). The role of isopod crustaceans in the reef crest community at Carrie Bow Cay, Belize. P.S.Z.N.I. Mar Ecol. 5: 29-44

Kimmerer, W. J., McKinnon, A. D. (1986). Glutaraldehyde fixation to maintain biomass of preserved plankton. J. Plankton Res. 8; 1003-1008

Klumpp, D. W., McKinnon, D., Daniel, P. (1987). Damselfish territories: zones of high productivity on coral reefs. Mar Ecol. Prog. Ser. 40: 41-51

Kohn, A. J., Leviten, P. J. (1976). Effect of habitat complexity on population density and species richness in tropical intertidal predatory gastropod assemblages. Oecologia (Berl.) 25: 199-210

Kohn, A. J., Lloyd, M. C. (1973). Polychaetes of truncated reef limestone substrates on eastern Indian Ocean coral reefs: diversity, abundance and taxonomy. Int. Revue ges. Hydrobiol. 58: 369-399

Leviten, P. J. (1978). Resource partitioning by predatory gastropods of the genus Conus on sub-tidal Indo-Pacific reefs the significance of prey size. Ecology 59: 614-631
Lobel, P. S. (1980). Herbivory by damselfishes and their role in coral reef community ecology. Bull. mar. Sci. 30: 273-289

Macko, S. A., Lee, W Y., Parker, P. L. (1982). Nitrogen and carbon isotope fractionation by two species of marine amphipods: laboratory and field studies. J. exp. mar Biol. Ecol. 63: 145-149

McBane, C. D., Croker, R. A. (1983). Animal-algal relationships of the amphipod Hyale nilssoni in the rocky intertidal. J. crust. Biol. 3: 592-601

Miller, A. C. (1982). Effects of differential fish grazing on the community structure of an intertidal reef flat at Enewetak Atoll, Marshall Islands. Pacif. Sci. 36: 467-482

Nicotri, M. E. (1977). Grazing effects of four marine intertidal herbivores on the microflora. Ecology 58: 1020-1032

Peters, R. H. (1983). The ecological implications of body size. Cambridge University Press, Cambridge

Peyrot-Clausade, M. (1980). Motile cryptofauna of Tuléar reef flats. Mar. Biol. 59: 43-47

Polunin, N. V., Koike, I. (1987). Temporal focussing of nitrogen release by a periodically-feeding herbivorous reeffish. J. exp. mar Biol Ecol. 111, 1-12

Reichelt, R. (1979). Infaunal polychaetes of reef crest habitats et Heron Island. Great Barrier Reef. Micronesica 15: 297-307

Risk, M. J., Sammarco, P. W. (1982). Bioerosion of corals and the influence of damselfish territoriality: a preliminary study. Oecologia (Berl.) 52: 376-380

Robertson, A. I., Mann, K. H. (1980). The role of isopods and amphipods in the initial fragmentation of eelgrass detritus in Nova Scotid, Canada. Mar. Biol. 59: 63-69

Robertson, A. I., Lucas, J. S. (1983). Food choice, feeding rates, and the turnover of macruphyte biomass by a surf-zone inhabiting amphipod. J. exp. mar Biol. Ecol. 72: 99-124

Russ, G. R. (1987). Is rate of removal of algae by grazers reduced inside territories of tropical damselfishes? J. exp. mar Biol. Ecol. 110: 1-17

Russo, A. R. (1987). Role of habitat complexity in mediating predation by the gray damselfish Abudefduf sordidus on epiphytal amphipods. Mar Ecol. Prog. Ser. 36: 101-105

Sale, P. F., McWilliam, P. S., Anderson, D. T (1976). Composition of the near-reef zooplankton at Heron Reef, Great Barrier Reef. Mar Biol. 34: 59-66

Sammarco, P. W. (1983). Effects of fish grazing and damselfish territoriality on coral reef algae. I. Algal community structure. Mar Ecol. Prog. Ser 13: 1-14

Sammarco, P. W., Williams, A. H. (1982). Damselfish territoriality: influence on Diadema distribution and implications for coral community structure. Mar. Ecol. Prog. Ser. 8: $53-59$

Sammarco, P. W., Carlton, J. H., Risk, M. J. (1986). Effects of grazing and damselfish territoriality on bioerosion of dead corals: direct effects. J. exp. mar. Biol. Ecol. 98: 1-19

Scott, F. J., Russ, G. (1987). Effects of grazing on species composition of the epilithic algal community on coral reefs of the central Great Barrier Reef. Mar. Ecol. Prog. Ser. 39: 293-304

Sellner, B. W. (1976). Survival and metabolism of the harpacticoid copepod Thomsonula hyaenae fed different diatoms. Hydrobiologia 50: 233-238

Steedman, H. F. (1976). Narcotizing agents and methods. In: Steedman, H. F. (ed.) Zooplankton fixation and preservation. The Unesco Press, Paris, p. 87-96

Stoner, A. W. (1985). Penicillus capitatus: an algal island for macrocrustaceans. Mar Ecol. Prog. Ser. 26: 279-287

Stoner, A. W. (1980). Perception and choice of substratum by epifaunal amphipods associated with seagrass. Mar Ecol. Prog. Ser. 3: 105-111 
Vadas, R. L. (1985). Herbivory. In: Littler, D. S., Littler, M. M. (eds.) Handbook of phycological methods. Ecological field methods: macroalgae. Cambridge University Press, Cambridge, p. 531-572

van Montfrans, J., Orth, R. J., Vay, S. A. (1982). Preliminary studies of grazing by Bittium varium on eelgrass periphyton. Aquat. Bot. 14:75-89

Vine, P. J. (1974). Effects of algal grazing and aggressive behavior of the fishes Pomacentrus lividus and Acanthurus sohal on coral reef ecology. Mar. Biol. 24: 131-136

Vivien, M. L., Peyrot-Clausade, M. (1974). Comparative study of the feeding behavior of three coral reef fishes (Holocentridae) with special reference to the Polychaeta of the reef cryptofauna as prey. In: Proc. 2nd Int. Symposium on Coral Reef. Symp. Great Barrier Reef Committee, Brisbane, p. $179-192$
Vollenweider, R. A. (1974). Sampling techniques and methods for estimating quantity and quality of biomass. In: Vollenweider, R. A. (ed.) A manual on methods for measuring primary production in aquatic environments. Blackwell Scientific Publications, Oxford, p. 46-50

Wakabara, Y., Tararam, A. S., Takeda, A. M. (1983). Comparative study of the amphipod fauna living on Sargassum of two Itanhaem shores, Brazil. J. crust. Biol 34: 602-607

Wilkinson, C. R., Sammarco, P. W. (1983). Effects of fish grazing and damselfish territoriality on coral reef algae. II. Nitrogen fixation. Mar. Ecol. Prog. Ser. 13: 15-19

Williams, A. H. (1981). An analysis of competitive interactions in a patchy back-reef environment. Ecology 62: 1107-1120

Zimmerman, R., Gibson, R., Harrington, J. (1979). Herbivory and detritivory among gammaridean amphipods from a Florida seagrass community. Mar. Biol. 54: 41-47

This article was submitted to the editor; it was accepted for printing on April 1, 1988 